\title{
Porter's Competitive Strategies Influence on Performance of Mobile Telecommunication Companies in Kenya
}

\author{
Asena Muganda David \\ Kibabii University School of Business and Economics P.O Box 1699-50200 Bungoma, Kenya
}

\begin{abstract}
:
The purpose of the study was to establish the relationship between Porter's competitive strategies and performance of mobile telecommunication companies in Kenya. More specifically the study sought to determine the influence of cost leadership, differentiation and market focus strategies on performance of mobile telecommunication companies in Kenya. The target population of the study comprised of 241 management staff drawn from; Safaricom PLC, Airtel, Telkom and Equitel mobile telecommunication companies in Kenya. A sample of 117 respondents was selected purposively for the study. The study adopted a mixed method of explanatory and cross sectional survey research design approach. The research utilized both primary and secondary data. The data obtained was summarized using descriptive and inferential statistics. Pearson's correlation was used to determine the relationship between the variables, and multiple regression to determine the influence of Porter's competitive strategies on performance of mobile telecommunication companies. The study concluded that Porter's competitive strategies; cost leadership, differentiation and market focus strategies adopted by the telecommunication companies had a positive significant influence on their performance in terms of sales and market share in customer's subscription. The study recommended that mobile telecommunication companies in Kenya should embrace Porter's competitive strategies more to continue achieving competitive advantage and enhance their performance.
\end{abstract}

Keywords: Porter's Competitive Strategies, Cost Leadership Strategies, Differentiation Strategies, Market Focus Strategies, Performance

\section{Introduction}

\subsection{Background of the Study}

In today's competitive business environment, organizations must map out their plans on how to sustain their business performance, competitive advantage and profitability. Thompson, Strickland and Gamble (2007) ascertained that the main objective of any strategy in an organization is to improve its financial performance and strengthen its competitive position. To obtain sustainable competitive advantage, the formulation and implementation of competitive business strategies that will improve performance is an important major issue to policy makers. Competitive strategy consists of all those moves and approaches that a firm has and is taking to attract buyers, withstand competitive pressure and improve its market position (Panayides, 2008).

Porter (2008) describes competitive strategy as the search for a favorable competitive position in an industry, the fundamental arena in which competition occurs. It aims at establishing a profitable and sustainable position against the forces that determine industry competition. This involves identifying sources of competition in the ever changing environment then developing strategies that match organizational capabilities to the changes in the environment thus it consists of all those moves and approaches that a firm has and is taking to attract buyers, withstand competitive pressure and improve its market position (Thompson \& Strickland, 2010). Porter (2000) outlined three approaches of competitive strategy as; low cost leadership, differentiation and market focus strategies. Lester (2009) argued that competitive strategy enables a firm to define its business and determine the industries or markets to compete.

Porter's arguments are drawn from the work of organizational economist who places the industry as the central focus of strategic attention. According to Porter's framework, structural characteristics of a 
firm's industry best explain variations in its performance. Using the language of economics a successful firm is one that appropriates monopolistic rents. In other words, in the industry as a whole or in a segment of the industry, the firm establishes itself as dominant (or sole) competitor. Porter's logical conclusion from this perspective is that there are only two ways to compete: through low cost or product differentiation. Cost leadership is achieved through the aggressive pursuit of economies of scale, product and process simplification and significant product market share that allows companies to exploit experience and learning effects. Differentiation calls for creating a product that the customer perceives as highly valuable and unique. Approaches to differentiation can take many forms: design of brand image, technology, features, and customer service and dealer networks. The strategic positions of low cost and differentiation are centered on product economics. The resulting mentality of this approach, which is widely apparent in the business world, has enormous implications of commoditization.

The fundamental basis of above-average performance in the long run is sustainable competitive advantage. The notion underlying the concept of generic strategies is that competitive advantage is at the heart of any strategy and achieving competitive advantage requires a firm to make a choice about the type of competitive advantage it seeks to attain and the scope within which it will attain. Though a firm can have a myriad of strengths and weaknesses vis-à-vis its competitors, there are two basic types of competitive advantage a firm can possess; low cost or differentiation. The two basic types of competitive advantage combined with the scope of activities for which a firm seeks to achieve them lead to three generic strategies for achieving above-average performance in an industry (Porter, 1985).

Kenya's telecommunication industry has grown tremendously over the years with the total number of mobile phone subscriber base standing at 42.8 million subscribers representing a penetration level of 94.3 as at December 2018. The competitive nature of the telecommunication industry in Kenya has seen the introduction of new players in the market, with the current players being Safaricom with a market share of $69.1 \%$; Bharti Airtel $17.2 \%$; Telekom Kenya 9.0\%; Equitel (Finserve Africa Limited) at 4.5\%; Tangaza money (Mobile Pay Limited) at $0.2 \%$ and Sema Mobile Services standing at $0 \%$ with a subscription of 295 subscribers (CA, 2018). The telecommunication industry environment has of late been affected adversely by the changing operating environment. Interestingly, while Safaricom is making the highest profits in East and Central Africa (CA, 2018), the other mobile service providers have been making huge losses that have led to their management to consider leaving the Kenyan market. Essar sought to bolt out and was bought by Bharti Airtel. Telekom Kenya adopted an aggressive stance, acquired the $3 \mathrm{G}$ licenses to expand into data market as a new source of revenues. Airtel also acquired the $3 \mathrm{G}$ license, but in addition led in a price war by slashing retail prices drastically so as to become the customer's preferred network. Airtel also sought to aggressively manage and control its costs in order to sustain the low retail prices. To accomplish this, it engaged in an aggressive effort to outsource its IT network and customer care functions. Safaricom realizing that revenues from voice business would continue to shrink focused on its data and mobile commerce business under the brand name M-PESA. In the telecommunication industry in Kenya, some of the firms have already gained a competitive advantage from the quality of the products they offer in the market. Safaricom limited has been on the lead with the M-pesa product that has been reaping a bigger slice of their profits (Talk Now-Telecom Africa, 2010) due to its inimitability. The M-pesa product has proven to be one of the best products in the industry since its inception for there has been an upward trend on the uptake of the firm's service since customers are tied to the network due to the advantages they get from the transaction services.

In the last five years, Safaricom remained the market leader with other network providers trying to outperform it by formulating all sorts of strategies like offering free calls and messages across the networks, offering cheaper services in mobile money transfer and other forms of advertisement but without much success. The stiff competition characterized by price wars among the mobile service providers in an attempt to win a larger market share, has seen drastic price cuts in the voice segment pioneered by Airtel (a drop from a high of Ksh. 8 per minute to Ksh. 3 in 2011), considered the biggest revenue earner for the mobile players in the industry, causing a decline on ARPUs (Ombok, 2009). This study therefore sought to unveil the influence of Porter's competitive strategies on the performance of mobile telecommunication companies in Kenya.

\subsection{Statement of the Problem}

The mobile market shares measured by the number of subscriptions have maintained a similar trend 
over a period with Safaricom PLC holding the largest market share in subscriptions despite it being in the midst of competition amongst rivals Airtel, Telekom Kenya and Finserve Africa (CA, 2018). In a perfect competitive market, consumers have freedom to choose from among the available alternative service providers. In such a case, the market leadership is expected to shift from one service provider to another, however that has not been the case of Kenyan mobile phone companies where the market leadership has been dominated by Safaricom PLC. Interestingly, while Safaricom is making the highest profits in East and Central Africa (CA, 2018), the other mobile service providers have been making huge losses that have led to their management to consider leaving the Kenyan market. This raises a big question on why are the other firms in the industry not able to measure up to the market leader Safaricom.

A number of Studies related to competitive strategies have been done in Kenya including Akingbade (2014) who examined competitive strategies and improved performance of selected Nigeria telecommunication companies and revealed that there is a positive relationship between competitive strategies, its constituents and performance of telecommunication companies. However, this study was carried out in Nigeria whose operational environment is different from Kenya hence the need to undertake the current study. Kapto and Njeru (2014) examined the strategies adopted by mobile phone companies in Kenya to gain competitive advantage and reveled there existed positive relationship between competitive strategies adopted and competitive advantage. This study however did not delve more to the specific influence of these strategies on the performance of the telecommunication firms under study. On the other hand, these studies have not found the reasons as to why some of these telecommunication firms have decided to exit the Kenyan market. This study sought to address those gaps intensively by analyzing Porter's competitive strategies influence on the performance of mobile telecommunication companies in Kenyan market.

\subsection{Research Objectives}

The general objective of the study was to determine the relationship between Porter's competitive strategies and performance of mobile telecommunication companies in Kenya. The specific objectives were:

1) To determine the relationship between cost leadership strategies and performance of mobile telecommunication companies in Kenya

2) To establish the relationship between differentiation strategies and performance of mobile telecommunication companies in Kenya.

3) To examine the relationship between market focus strategies and performance of mobile telecommunication companies in Kenya.

\subsection{Research Hypotheses}

This paper focused on addressing the following three research objectives:

Ho: : Cost leadership strategies have no significant relationship on the performance of mobile telecommunication companies in Kenya.

Ho2: Differentiation strategies have no significant relationship on the performance of mobile telecommunication companies in Kenya.

Ho3: Market focus strategies have no significant relationship on the performance of mobile telecommunication companies in Kenya.

\subsection{Literature Review}

\subsection{Porter's Competitive Strategies}

Porter (2003) proposes a strategy that requires a firm to identify growth segments, work at achieving operational efficiency and continuously enhance the quality of its products and services. It is the continuous measurement of these performance indicators and their management that determines the long term direction of the firm and its survival. For the telecommunication industry in Kenya, not only is the continuous measurement of the key performance metrics important to achieve and maintain competitiveness, but also the strategy formulation and implementation process as well. Porter (1980) distinguishes three different strategies, namely cost leadership, differentiation, and market focus. Porter proposes that one of these three generic strategies has to be pursued in order to maintain a competitive advantage (Porter; 1980).

\subsubsection{Cost Leadership Strategies}

In cost leadership, a firm sets out to become the lowcost producer in its industry. The sources of cost advantage are varied and depend on the structure of the industry. They may include pursuit of economies of scale, proprietary technology, preferential access to raw materials among others (Porter, 1985). Cost leadership tends to be more competitors oriented 
rather than customer oriented. It requires a strong focus on the supply side as opposed to the demand side of the market, as this requires a high level of competitor orientation. Therefore, firms pursuing a cost leadership strategy must continuously benchmark themselves against other competing firms in order to assess their relative cost (and therefore profitability) position in the market place. A firm that pursues cost leadership strategy achieves a low-cost position by emphasizing on "aggressive construction of efficient-scale facilities, vigorous pursuit of cost reductions from experience, tight cost and overhead control, avoidance of marginal customer accounts, and cost minimization in areas like research and development (R\&D), services, sales force, advertising, etc" (Porter, 1980). If a firm can achieve and sustain overall cost leadership, then it will be an above-average performer in its industry provided it can command prices than its rivals. A cost leader's low-cost position translates into higher returns.

\subsubsection{Differentiation Strategies}

In a differentiation strategy, a firm seeks to be unique in its industry along some dimensions that are widely valued by buyers (Porter, 1985). It selects one or more attributes that many buyers in an industry perceive as important, and uniquely positions itself to meet those needs. It is rewarded for its uniqueness with a premium price. Dirisu, Oluwole and Ibidunni (2013) concluded that, there is a positive relationship between firms that pursue product differentiation through product innovation, product design, higher quality product or unique product and the firm performance; Dirisu et al (2013) further confirmed that product differentiation could be used as a tool to achieve product leadership and thus enhance organization performance. On the other hand Prajogo (2007) examined the underlying strategic intent of quality performance and the result of his findings showed that product quality is predicted by differentiation strategy, but not cost leadership strategy. The choice of what product to purchase in most consumer markets is not majorly determined by the lowest price, but the product's quality. Product quality can have large effects on demand and consumer welfare and has been recognized as a strategic organizational priority, it is also an important element of competition in a wide range of markets and industries.

\subsubsection{Market Focus Strategies}

Focus means producing products and services that fulfill the needs of small groups of consumers. There are two types of focus strategy namely low-cost focus strategy that offers products or services to a small range (niche group) of customers at the lowest price available on the market. The other type of focus strategy is best-value available on the market. Caxton (2015) expresses, a firm using a focus strategy often enjoys a high degree of customer loyalty, and this entrenched loyalty discourages other firms from competing directly. Because of their narrow market focus, firms pursuing a focus strategy have lower volumes and therefore less bargaining power with their suppliers. However, firms pursuing a differentiation-focused strategy may be able to pass higher costs on to customers since close substitute products do not exist. Firms that succeed in a focus strategy are able to tailor a broad range of product development strengths to a relatively narrow market segment that they know very well. Some risks of focus strategies include imitation and changes in the target segments. Furthermore, it may be fairly easy for a broadmarket cost leader to adapt its product in order to compete directly. Finally, other focusers may be able to carve out sub-segments that they can serve even better.

\subsection{Organization Performance}

The fundamental purpose of every organization is to consistently outperform the competition and deliver sustained, superior returns to the owners while satisfying other stakeholders. It comprises of the actual output or results of an organization as measured against its intended outputs (Ongeti, 2014). It considers all non-financial and financial results of an organization and it's not restricted to economic outcomes (Upadhaya, Munir \& Blount, 2014). Richard, Devinny, Yip and Johnson (2009) explains that organizational performance encompasses three specific areas of firms outcome namely, financial performance (profits, return on assert, return on investment); product market performance (sales, market share); and shareholders return (total shareholder return, economic value added). Combs, Crook and Shook (2005) views performance as an "economic outcome" resulting from the interplay among organizational attributes, actions and environment. The yard stick with which organizational performance is measured cannot be the same across all organizations. Many organizations have attempted to measure organizational performance using the balanced scorecard methodology where performance is tracked and measured in multiple dimensions such as financial, internal business processes, customer and learning and growth (Kaplan \& Norton, 2001). 


\subsubsection{Balanced Scorecard}

The balanced scorecard offers both qualitative and quantitative measures that acknowledge the expectations of different stake holders and related to assessment of performance in choice of strategy. It allows managers to look at the business from four important perspectives namely; the customer perspective which deals with critical success factors which include market share, customer retention rates and relevant products; the internal business perspective deals with critical success factors which include process cycle times, and productivity or capacity utilization; the financial perspective deals with critical success factors which include survival, profitability and revenues; the innovation and learning perspective which takes into consideration the critical success factors which include training, quality improvement and service leadership. The ability to launch new products, create more value for customers and improve operating efficiencies continually results in penetration of new markets, increase in revenues and margins (Kaplan \& Norton, 2001). The four perspectives permit a balance between short-and long-term objectives, between outcomes desired and the performance drivers of those outcomes, and between hard objective measures and softer, more subjective measures".

In Kaplan and Norton's view (1996), strategies are developed following a cause and effect approach. The measurement system should make the relationships

Cost Leadership Strategies

- Scale Economics

- Low Input Costs

- Standard Qualities among objectives (and

measures) in the various perspectives explicit so that they can be managed and validated (Kaplan \& Norton, 1996, p. 30). For example, investments in learning will lead to a better internal business process, which, in turn, is likely to improve a customer's satisfaction and loyalty, and therefore result in a higher return on investments, which would satisfy shareholders. It can therefore be argued that while there are many other factors that contribute to organizational performance, the current study sought to unveil the relationship between Porter's competitive strategies and performance mobile telecommunications industry in Kenya

\subsection{Conceptual Framework}

The conceptual framework developed for this research was intended to assist the researcher to develop an understanding of the relationship between Porter's competitive strategies and performance of mobile telecommunication companies in Kenya. Figure 2.3 illustrates the conceptualized relationship between the independent variables cost leadership; differentiation and market focus strategies; dependent variable organization performance and intervening variable government policies and taxes.

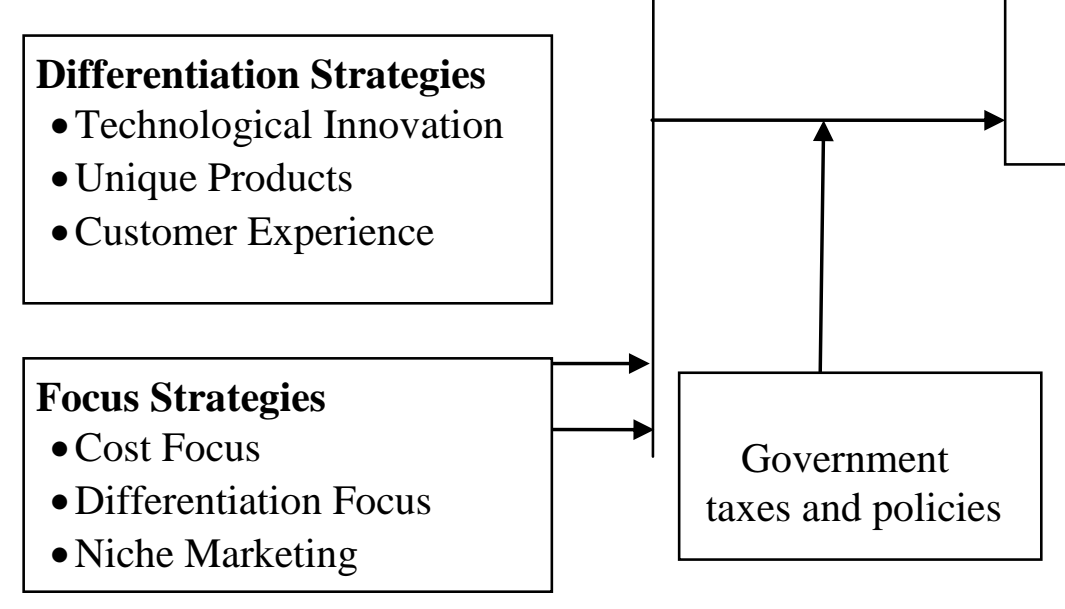

Independent Variables

\section{Organization Performance}

- Market ShareCustomer Subscription

- Customer Retention

- Operational Efficiency

- Overall Profitability

Figure 2.3: Conceptual Framework 


\subsection{Empirical Literature}

\subsubsection{Porter's Competitive Strategies Influence on Performance}

Afande (2015) examined competitive strategies and firm performance in the mobile telecommunication service industry using a case of Safaricom Kenya Limited. The findings also show that the strategies adopted by Safaricom Kenya Limited included vigorous pursuit of cost reductions; providing outstanding customer service; improving operational efficiency; controlling quality of products/services; intense supervision of frontline personnel; developing brand or company name identification; targeting a specific market niche or segment; and providing specialty products/services. This study was only a case of one organization yet the current study is a cross-sectional study cutting across several players in the telecommunication industry.

Chesire and Kombo (2015) studied the relationship between Porter's Competitive strategies and performance of value added services by mobile phone operators in Kenya. The overall objective of the study was to determine the effect of competitive strategies on the performance of Mobile Value Added Services. The study pointed out that as a result of the stiff competition amongst the telecommunication firms in the Kenyan market, the firms have adopt various strategies in the provision of mobile value added services to remain competitive. The study found out that there is a significant relationship between cost leadership, differentiation and focus affects performance of the MVAS services. To excel in low cost leadership, the telecommunication companies maximized on economies of scale, implemented cost cutting technologies and also applied cost leadership by enhancing a tight control of overheads. In differentiation, product differentiation was adopted to a great extent with companies seeking to make unique characteristics of their products and further trying to make sure that their competitors do not imitate their products. On focus strategy, the firms greatly made unique product attributes for chosen segments, introduced customer service for chosen segments and also products and services for low priced market segments. The study concluded that the strategies adopted by the telecommunication companies had an effect on the performance of the
MVAS in terms of growth of sales and market share. The study was limited to MVAS and not the company as a whole which is the case of the current study

\subsection{Research Methodology}

This study adopted a positivist epistemological research philosophy which is an objective-based method and could be used to test hypothesis from existing theories. It also adopted a mixed method approach design made of explanatory research design and cross-sectional survey design. The targeted population consisted of 241 managers drawn from the four mobile telecommunication companies in Kenya; Safaricom PLC, Airtel Kenya, Telkom Kenya and Equitel. Nassiuma (2000) propounded formula was used to determine the actual sample of 117 respondents. The study adopted stratified proportionate random sampling technique to obtain a fair representation of subgroups of the sample size since the sampling frame was not homogeneous. The study relied on both primary and secondary data. Primary data was collected using self-administered questionnaires while secondary data from institution publications, CA publications and referred journals. Pearson correlation analysis was conducted in order to establish the nature and strength of Porter's competitive strategies influence on performance of mobile telecommunication companies. Multiple linear regression analysis was conducted to generate a measure of the degree of association, appropriate at 95 percent confidence level $(\alpha=0.05)$. The multiple regression equation used to assess the predictive effect of two independent variables (X and $\mathrm{Z}$ ) on $\mathrm{Y}$ is:

$$
\begin{aligned}
& \mathrm{Y}=\beta_{0}+\beta_{1} X_{1}+\beta_{2} X_{2}+\beta_{3} X_{3}+\varepsilon \\
& \text { Whereby: } \\
& \mathrm{Y}=\text { Performance, } \\
& \beta_{0}=\text { Constant } \\
& \alpha=\text { Constant (intercept) } \\
& \beta_{1} \text { Is the coefficient of } X_{1} \text { for } \mathrm{i}=1,2, \\
& 3 \\
& X_{1}=\text { Cost Leadership Strategies, } \\
& X_{2}=\text { Differentiation Strategies, } \\
& X_{3}=\text { Market Focus Strategies }
\end{aligned}
$$


International Journal of Scientific Research and Management (IJSRM)

||Volume||07||Issue||02||Pages||EM-2019-1014-1022||2019||

Website: www.ijsrm.in ISSN (e): 2321-3418

Index Copernicus value (2016): 93.67, (2017):89.90, DOI: 10.18535/ijsrm/v7i2.em05

\subsection{Results and Discussions}

\subsection{Correlation Analysis}

Pearson's correlations analysis was conducted at 95\% confidence interval so as to establish the relationship between the Porter's competitive strategies and performance of mobile

telecommunications companies in Kenya.

Table 4.1: Correlation Matrix

\begin{tabular}{|c|c|c|c|c|c|}
\hline & & $\begin{array}{l}\text { Organizational } \\
\text { Performance }\end{array}$ & $\begin{array}{l}\text { Cost } \\
\text { Leadership } \\
\text { Strategies }\end{array}$ & $\begin{array}{l}\text { Differentiation } \\
\text { Strategies }\end{array}$ & $\begin{array}{l}\text { Market } \\
\text { Focus } \\
\text { Strategies }\end{array}$ \\
\hline \multirow[t]{2}{*}{$\begin{array}{l}\text { Organization } \\
\text { Performance }\end{array}$} & $\begin{array}{l}\text { Pearson } \\
\text { Correlation }\end{array}$ & 1 & & & \\
\hline & $\begin{array}{l}\text { Sig. (2- } \\
\text { tailed) }\end{array}$ & & & & \\
\hline \multirow{2}{*}{$\begin{array}{l}\text { Cost } \\
\text { Leadership } \\
\text { Strategies } \\
\end{array}$} & $\begin{array}{l}\text { Pearson } \\
\text { Correlation }\end{array}$ & $.593 * *$ & 1 & & \\
\hline & $\begin{array}{l}\text { Sig. (2- } \\
\text { tailed) }\end{array}$ & 0.04 & & & \\
\hline \multirow[t]{2}{*}{$\begin{array}{l}\text { Differentiation } \\
\text { Strategies }\end{array}$} & $\begin{array}{l}\text { Pearson } \\
\text { Correlation }\end{array}$ & $.637 * *$ & $.634 *$ & 1 & \\
\hline & $\begin{array}{l}\text { Sig. (2- } \\
\text { tailed) }\end{array}$ & .011 & .032 & & \\
\hline \multirow[t]{3}{*}{$\begin{array}{l}\text { Market Focus } \\
\text { Strategies }\end{array}$} & $\begin{array}{l}\text { Pearson } \\
\text { Correlation }\end{array}$ & $.671 *$ & $.667 *$ & $.733^{*}$ & 1 \\
\hline & $\begin{array}{l}\text { Sig. (2- } \\
\text { tailed) }\end{array}$ & .005 & .003 & .020 & \\
\hline & $\mathrm{n}$ & 117 & 117 & 117 & \\
\hline
\end{tabular}

**Correlation is Significant at the 0.01 (2-tailed)

*Correlation is Significant at the 0.05 level (2-tailed)

The results showed that there was a significant positive correlation between cost leadership strategies and performance with a correlation coefficient $(r=.593 ; \mathrm{p}<0.04)$. The correlation between differentiation strategies and performance was also positively significant with a coefficient $(\mathrm{r}=.637 ; \mathrm{p}<0.011)$. There is also a significant positive significant correlation between market focus strategies and performance with a correlation coefficient $(r=.671 ; \mathrm{p}<0.05)$. This is in line with Bisungo, Chege, and Musiega (2014) who found that a positive relationship existed between competitive strategies and the volume of sales that the firm made. Bisungo, et.al. (2014) argued that

\subsection{Multiple Regression}

A regression analysis was conducted to determine how the cost leadership, differentiation, and market
Porter's competitive strategies do not work in isolation but support one another in producing the effects. Porter (1980) affirms this position and notes that a firm can achieve a higher level of performance over a rival in one of two ways: either it can supply an identical product or service at a lower cost, or it can supply a product or service that is differentiated in such a way that the customer is willing to pay a price premium that exceeds the additional cost of the differentiation. In the former case, the firm possesses a cost advantage. In the latter, the firm possesses a differentiation advantage. In pursuing cost advantage, the goal of the firm is to become the cost leader in its industry or industry segment.

focus strategies influence on performance of mobile telecommunications companies in Kenya 
International Journal of Scientific Research and Management (IJSRM)

||Volume||07||Issue||02||Pages ||EM-2019-1014-1022||2019||

Website: www.ijsrm.in ISSN (e): 2321-3418

Index Copernicus value (2016): 93.67, (2017):89.90, DOI: 10.18535/ijsrm/v7i2.em05

Table 4.2: Multiple Regression Model

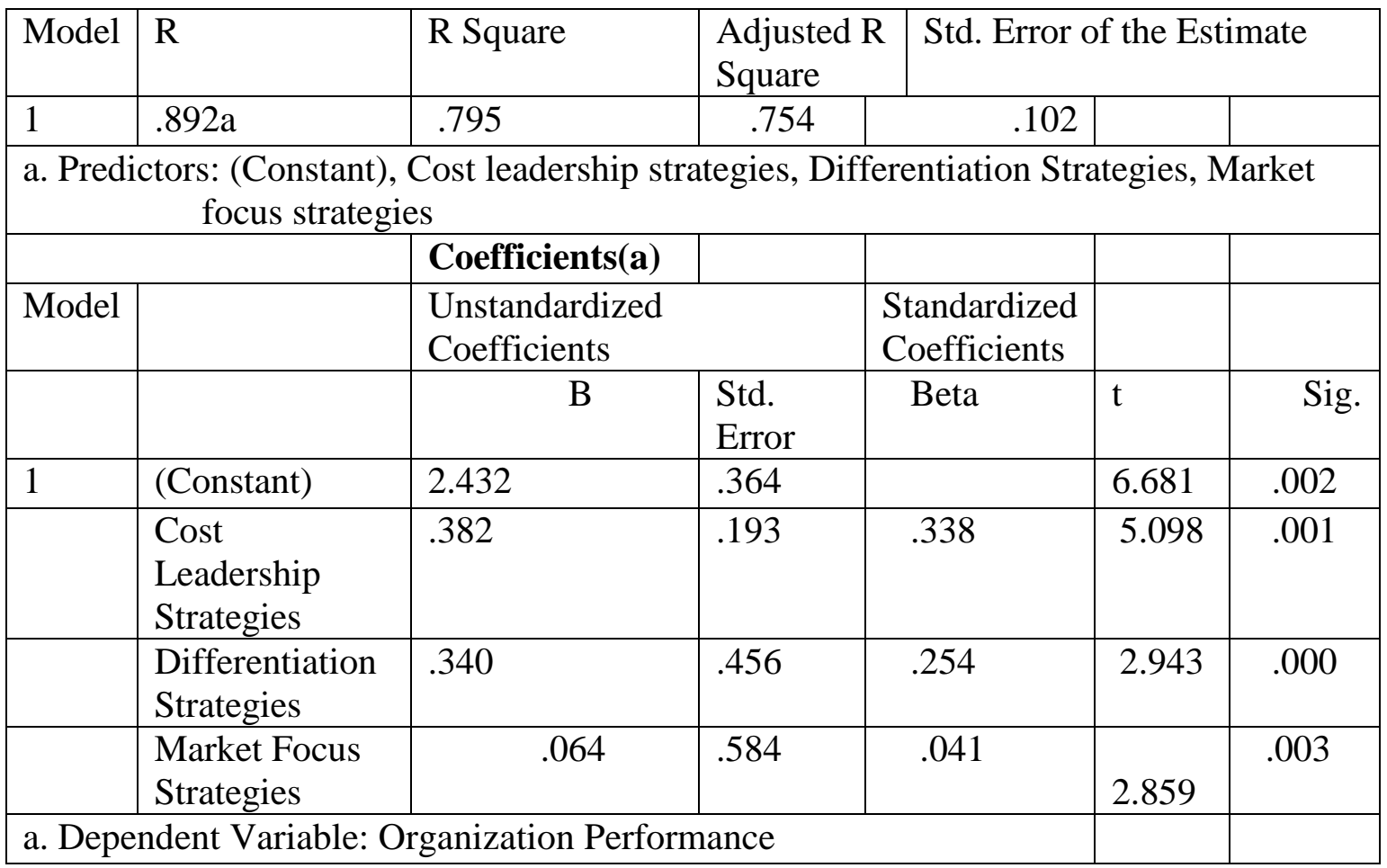

The findings from Table 4.2 shows that the adjusted $\mathrm{R}$ squared value is 0.754 implying that $75.4 \%$ variation of performance of mobile telecommunication companies is explained by the variables cost leadership; differentiation and market focus strategies. The results further affirms that cost leadership strategies has a positive influence on performance of mobile telecommunication companies in Kenya $\left(\beta_{1}=0.338\right)$. This is in line with the finding by Hyatt (2001). Hyatt ascertained that in order to achieve a low-cost advantage, an organization must have a low-cost leadership strategy, low-cost manufacturing, and a workforce committed to the low-cost strategy. The organization therefore must be willing to discontinue any activities in which they do not have a cost advantage and should consider outsourcing activities to other organizations with a cost advantage. Differentiation strategies has a positive influence on performance mobile telecommunication companies in Kenya with a coefficient $\left(\beta_{2}=0.254\right)$ which is positive. The findings in this study confirm that of Arasa and Gathinji (2014) who found that the most employed competitive strategies were low cost, differentiation of products and strategic alliance. They concluded that manufacturing firms that employed these strategies realized increase in their sales and market shares, customer retention, profitability and product innovation. Reilly (2002) also found out that product differentiation fulfills a customer need and involves tailoring the product or service to the customer, this allows organizations to charge a premium price to capture market share. Differentiation strategy is effectively implemented when the business provides unique or superior value to the customer through product quality, features, or after-sale support. Firms following a differentiation strategy can charge a higher price for their products based on the product characteristics, the delivery system, the quality of service, or the distribution channels. The differentiation strategy appeals to a sophisticated or knowledgeable consumer interested in a unique or quality product and willing to pay a higher price. Market focus strategies was also found to have a positive influence on performance of mobile telecommunication companies in Kenya with a positive coefficient of $\left(\beta_{3}=0.041\right)$. The finding above concurs with the study findings by Porter, (2005), that a successful focus strategy depends upon an industry segment large enough to have good growth potential but not of key importance to other major competitors' market penetration or market development therefore can be an important focus strategy. 


\subsection{Research Hypotheses Testing}

Ho1: Cost leadership strategies have no significant relationship on the performance of mobile telecommunication companies in Kenya. From Table 4.2; It is shown that the coefficient of cost leadership strategies is significant $(p=.001$ $<0.005$ ) in relation to performance of mobile telecommunication companies in Kenya. Thus we reject the null hypothesis $\left(\mathrm{Ho}_{1}\right)$ on the basis of sample data.

Ho2: Differentiation strategies have no significant relationship on the performance of mobile telecommunication companies in Kenya. From Table 4.2; It is shown that the coefficient of differentiation strategies is significant $(p=.000$ $<0.005)$ in relation to performance of mobile telecommunication companies in Kenya. Thus we reject the null hypothesis $\left(\mathrm{Ho}_{2}\right)$ on the basis of sample data.

Ho3: Market focus strategies have no significant relationship on the performance of mobile telecommunication companies in Kenya. From Table 4.2; It is shown that the coefficient of market focus strategies is significant $(p=.003<$ 0.005 ) in relation to performance of mobile telecommunication companies in Kenya. Thus we reject the null hypothesis $\left(\mathrm{Ho}_{3}\right)$ on the basis of the sample data.

\subsection{Conclusion}

The study concludes that Porter's competitive strategies influence the performance of mobile telecommunication companies in Kenya. The study concluded that firms that chose to adopt cost leadership strategy focused on gaining competitive advantage by having the lowest cost in the industry. The firms can decide to sell its products either at average industry prices to earn a profit higher than that of rivals, or below the average industry prices to gain market share. Firms that adopted market focus strategies allowed them to provide superior customer service by offering them services not offered by competitors and also introducing new services in the market. Those that adopted differentiation strategies, conforms to specifications that greatly influence the reliable performance of the product, ensures quality systems from the coherence of process capabilities and lastly provide many unique and superior products to the market. On overall Porter's competitive strategies pursued by mobile telecommunication companies improves their overall performance in sales and market share; customer retention; profitability and product development/innovation. The study also recommends that firms that choose to employ market focus strategies should concentrate on a narrow segment and within that segment attempt to achieve either a cost advantage or differentiation to enjoy a high degree of customer loyalty, and discourage other firms from competing directly. The study recommended that the firms should embrace Porter's competitive strategies more to continue achieving competitive advantage and enhance their performance.

\section{References}

[1] Chesire, B. J. \& Kombo, H. (2015). Relationship between Porter's Competitive Strategies and Performance of Value Added Services by Mobile Phone Operators in Kenya. International Journal of Science and Research. 4(10), 976-983

[2] Combs, J. G., Crook, T. R., \& Shook, C. L. (2005). The Dimensionality of Organizational Performance and its Implications for Strategic Management Research, Research Methodology in Strategy and Management pp.259-286

[3] Communication Authority of Kenya. (December 2018). Second Quarter of the Financial Year 2017/2018. Retrieved on $4^{\text {th }}$ December 2018 from www.ca.go.ke

[4] Dirisu, J.I., Oluwole, I. \& Ibidunni, O. S. (2013). Product Differentiation: A tool of Competitive Advantage and Optimal Organizational Performance (A study of Unilever Nigeria PLC). European Scientific Journal. 9(34), 258-282

[5] Hyatt, L. (2008). A Simple Guide to Strategy, Nursing Homes, 50(1), 12-13.

[6] Kaplan, R. S. \& Norton, D. P. (2001).Transforming the Balanced Scorecard from Performance Measurement to Strategic Management: Part I. Accounting Horizons: 15(1), 87-104.

[7] Kaplan, R.S. \& Norton, D. P. (2006).The Balanced Scorecard: Translating Strategy into Action. Boston: The Harvard Business School Press.

[8] Kaplan, R.S. \& Norton, D.P. (1996). Strategic Learning and the Balanced Scorecard, Strategy \& Leadership, 24 (5), 18-24.

[9] Kaplan, R.S. \& Norton, D.P. (2004). The Strategy Map: Guide to Aligning Intangible Assets, Strategy \& Leadership, 32 (5), 1017.

[10] Kaplan, R.S. \& Norton, D.P. (1992). The Balanced Scorecard: Measures that Drive 
Performance. Harvard Business Review, 70(1), 71-79.

[11] Kapto, J. S. \& Njeru, A. (2014). Strategies Adopted By Mobile Phone Companies in Kenya to Gain Competitive Advantage. European Journal of Business Management, 2(1), 352-367.

[12] Lester, R. (2009). Made in America, MIT Commission on Industrial Productivity, Boston.

[13] Nassiuma D. K. (2000). Survey Sampling: Theory and Methods. Njoro, Kenya: Egerton University Press.

[14] Ongeti, W. J. (2014). Organizational Resources, Corporate Governance and Performance of Kenyan State Corporations. Unpublished $\mathrm{PhD}$ Thesis. Nairobi: University of Nairobi.

[15] Ombok, E. (2009). "Data Rise to Offset Voice Revenue" Retrieved on $11^{\text {th }}$ September 2017 from https://www.bloomberg.com

[16] Pearce, J. A. \& Robinson, R. (2007). Strategic Management: - Strategic Formulation and Implementation. Richard D. Irwin Inc. U.S.A. $3^{\text {rd }}$ Edition.

[17] Porter, M. (1980). Competitive Strategy: Techniques for Analyzing Industries and Competitors. New York: Free Press
[18] Porter, M. E. (1985). Competitive Advantage: Creating and Sustaining Superior Performance. New York: Free Press

[19] Porter, M. (1996), "What is strategy?" Harvard Business Review, November/December, pp. 61-78.

[20] Porter, M. E. (2008). Competitive advantage: Creating and sustaining superior performance. Simon and Schuster.

[21] Porter M.E., (2012). Competitive strategy: Techniques for analyzing industries and competitors, Free Press, New York.

[22] Prajogo, D. I. (2007). The Relationship between Competitive Strategies and Product Quality. Industrial Management \& Data Systems, 107(1), 69-83

[23] Richard, P. J., Devinney, T. M., Yip, G. S., \& Johnson, G. (2009). Measuring Organizational Performance: Towards Methodological Best Practice. Journal of Management, 35(3), 718-804.

[24] Thompson A. \& Strickland A. J. (2010). Strategic management: Concepts and Cases, Irwin, New York.

[25] Upadhaya, B., Munir, R. \& Blount, Y. (2014); Association between Performance Measurement Systems and Organizational Effectiveness; International Journal of Operation and Production Management, 34(7), 2-2 